\title{
Kemampuan Pemahaman Konsep Matematika terhadap Kemampuan Koneksi Matematika Siswa pada Materi Perbandingan
}

\author{
Rika Wahyuni $^{1}$, Nindy Citroresmi Prihatiningtyas ${ }^{2}$ \\ STKIP Singkawang, Singkawang, Indonesia \\ rikawahyuni142@gmail.com ${ }^{1, *)}$, nindy.citroresmi@ gmail.com ${ }^{2}$ \\ ${ }^{*}$ Corresponding author
}

\section{Kata kunci :}

Pemahaman Konsep; Koneksi

Matematika; Perbandingan

\begin{abstract}
ABSTRAK
Penelitian ini bertujuan untuk mendeskripsikan kemampuan pemahaman konsep dan koneksi matematika siswa pada materi perbandingan serta menganalisis keterkaitan kemampuan pemahaman konsep terhadap kemampuan koneksi matematika. Metode penelitian ini adalah metode penelitian kualitatif. Subjek dalam penelitian ini adalah siswa kelas VIII B SMP Negeri 14 Singkawang yang berjumlah 22 orang. Data diperoleh melalui tes kemampuan pemahaman konsep dan koneksi matematika serta pedoman wawancara yang tidak terstruktur. Data dianalisis melalui reduksi data, penyajian data, dan penarikan kesimpulan yang mengacu pada pendapat Miles and Huberman. Hasil analisis menunjukkan: (1) tingkat kemampuan pemahaman konsep matematika siswa pada materi perbandingan adalah 2 siswa dengan kemampuan pemahaman konsep tinggi, 7 siswa dengan kemampuan pemahaman konsep sedang dan 13 siswa dengan kemampuan pemahaman konsep rendah; (2) tingkat kemampuan koneksi matematika siswa pada materi perbandingan adalah 1 siswa dengan kemampuan koneksi tinggi, 5 siswa dengan kemampuan koneksi sedang dan 16 siswa dengan kemampuan koneksi rendah; (3) tingkat kemampuan pemahaman konsep matematika berkaitan dengan tingkat kemampuan koneksi matematika dengan rincian indikator menyatakan ulang sebuah konsep berkaitan dengan memahami hubungan antartopik matematika, indikator memberikan contoh dan noncontoh dari konsep matematika berkaitan dengan menerapkan konsep matematika dengan topik disiplin ilmu lainnya serta indikator mengaplikasikan konsep atau algoritma ke pemecahan masalah berkaitan dengan menerapkan konsep matematika dalam kehidupan sehari-hari.
\end{abstract}

\section{PENDAHULUAN}

Matematika sekolah adalah matematika yang diajarkan di satuan pendidikan dengan materi matematika dan pola pikir matematika terpilih yang disesuaikan dengan kebutuhan penerapannya dalam kehidupan sehari-hari dan perkembangan ilmu pengetahuan. Satuan pendidikan disini yaitu SD/MI, SMP/MTs dan SMA/Aliyah, tidak di jenjang perguruan tinggi. Menurut Prihatiningtyas \& 
Nurhayati (2017: 13) dalam pembelajaran matematika, idealnya siswa dibiasakan untuk memperoleh pemahaman melalui pengalaman dan pengetahuannya yang dikembangkan oleh siswa sesuai dengan perkembangan berpikirnya. Adapun fungsi mata pelajaran matematika menurut Hernawan dkk. (2010: 8.27) adalah untuk mengembangkan kemampuan berkomunikasi dengan menggunakan bilangan dan simbol-simbol serta ketajaman penalaran yang dapat membantu memperjelas dan menyelesaikan permasalahan dalam kehidupan sehari-hari. Dari kemampuan bernalarnya maka seseorang dimungkinkan untuk dapat memahami suatu konsep yang kemudian digunakan untuk memecahkan masalah (Mariyam \& Wahyuni, 2016: 74).

Pengertian matematika menurut Karso dkk. (2007: 1.40) adalah suatu ilmu yang berhubungan dengan penelaahan bentuk-bentuk atau struktur-struktur yang abstrak dan hubungan di antara hal-hal itu. Untuk dapat memahami struktur serta hubungan-hubungannya diperlukan penguasaan tentang konsepkonsep yang terdapat dalam matematika. Hal ini berarti belajar matematika adalah belajar konsep dan struktur yang terdapat dalam bahan-bahan yang sedang dipelajari serta mencari hubungan di antara konsep dan struktur tersebut. Belajar konsep berarti siswa harus memahami konsep-konsep yang ada. Pemahaman dapat diartikan menguasai sesuatu dengan pikiran (Sardiman, 2016: 43). Karena itu belajar berarti harus mengerti secara mental makna dan filosofinya, maksud dan implikasi serta aplikasi-aplikasinya, sehingga menyebabkan siswa dapat memahami suatu situasi. Hal ini sangat penting bagi siswa yang belajar. Tanpa pemahaman, skill pengetahuan dan sikap tidak akan bermakna. Pemahaman tidak sekedar tahu, tetapi juga menghendaki agar subjek belajar dapat memanfaatkan bahan-bahan yang telah dipahami. Maka pemahaman konsep matematika adalah kemampuan dalam menyerap ide-ide matematika, artinya siswa tidak sekedar menghafal tetapi benar-benar paham akan konsep yang mereka pelajari, sehingga dapat mengaplikasikannya pada suatu masalah secara efektif dan efisien.

Kemudian, teorema konektivitas (Ibrahim \& Suparni, 2012:87) menyatakan bahwa dalam pembelajaran matematika, tugas guru bukan hanya membantu siswa dalam memahami konsep-konsep, prinsip-prinsip serta memiliki keterampilan-keterampilan tertentu, tetapi juga membantu siswa dalam memahami hubungan antara konsep-konsep, prinsip-prinsip dan keterampilan-keterampilan tersebut. Kemampuan yang dimiliki siswa dalam memahami keterkaitan suatu konsep, materi serta topik dalam matematika maupun bukan matematika sehingga menjadi satu-kesatuan yang utuh disebut kemampuan koneksi matematika. Dengan memahami hubungan antara bagian yang satu dan yang lain dari matematika, pemahaman siswa terhadap struktur serta isi matematika menjadi lebih utuh. Karso dkk. (2007: 1.41) juga menegaskan bahwa matematika adalah ilmu tentang hubungan, karena dalam matematika konsep-konsepnya satu sama lain saling berhubungan.

Teori Ausubel juga menyatakan bahwa belajar seharusnya merupakan asimilasi yang bermakna bagi siswa. Materi yang dipelajari diasimilasikan dan dihubungkan dengan pengetahuan yang telah dimiliki siswa dalam bentuk struktur kognitif. Teori ini banyak memusatkan perhatiannya pada konsepsi, bahwa perolehan dan retensi pengetahuan baru merupakan fungsi dari struktur kognitif yang telah dimiliki siswa. Proses belajar akan berjalan dengan baik jika materi pelajaran atau informasi baru dapat beradaptasi dengan struktur kognitif yang telah dimiliki seseorang (Lestari \& Yudhanegara, 2015: 34).

Hal ini berarti terdapat hubungan antara kemampuan pemahaman konsep matematika terhadap kemampuan koneksi matematika siswa. Misalnya, pada indikator kemampuan koneksi matematika yaitu hubungan antartopik dalam bidang matematika, siswa akan dapat menghubungkan antar materi atau topik matematika apabila mereka memahami konsep setiap materi yang telah dipelajari, baik itu perbedaan atau kesamaan pada setiap materi. Dalam hal ini, apabila siswa tidak memiliki kemampuan pemahaman konsep pada setiap materi dengan baik maka mereka akan kesulitan untuk menghubungkan antartopik matematika. Oleh karena itu, jika kemampuan pemahaman konsep siswa baik, maka diduga kemampuan koneksi mereka juga akan baik. 
Namun, kemampuan pemahaman konsep matematika siswa belum maksimal. Hal ini dibuktikan dari hasil penelitian Suryani (2016: 112) yang menunjukkan bahwa tingkat kemampuan pemahaman konsep matematika tergolong rendah, yaitu 1) kemampuan menyatakan ulang sebuah konsep sebesar $40 \%$, dengan kategori rendah; 2) kemampuan mengklasifikasikan objek menurut sifat sesuai dengan konsepnya sebesar 33\%, dengan kategori rendah; 3) kemampuan menyajikan konsep ke dalam berbagai macam bentuk representasi matematis sebesar 57\%, dengan kategori sedang; 4) kemampuan menggunakan, memanfaatkan dan memilih prosedur tertentu sebesar 34\%, dengan kategori rendah. Selain itu, hasil prariset yang peneliti lakukan kepada 24 siswa kelas VII di SMP Negeri 14 Singkawang dengan materi himpunan di semester ganjil tahun ajaran 2017/2018 menunjukkan kemampuan pemahaman konsep dan koneksi matematika siswa tergolong rendah.

Perbandingan adalah membandingkan dua besaran atau lebih yang sejenis dalam bentuk sederhana dan merupakan salah satu materi matematika yang dipelajari di kelas VII semester genap. Materi ini banyak digunakan di dalam kehidupan sehari-hari, seperti membandingkan tinggi badan, panjang suatu benda dan sebagainya. Menerapkan konsep perbandingan di dalam dunia nyata merupakan salah satu indikator kemampuan koneksi matematika, untuk itu kemampuan pemahaman konsep sangat mempengaruhi tingkat keberhasilan belajar siswa.

Jadi dapat disimpulkan bahwa kemampuan pemahaman konsep matematika dapat berdampak pada kemampuan koneksi matematika siswa. Oleh karena itu, perlu dilakukan penelitian dengan judul "Kemampuan Pemahaman Konsep Matematika terhadap Kemampuan Koneksi Matematika Siswa pada Materi Perbandingan".

\section{METODE PENELITIAN}

Jenis penelitian ini adalah penelitian kualitatif. Dengan menggunakan metode ini maka hal yang akan dilakukan antara lain pengamatan, wawancara atau penelaahan dokumen sehingga hasil penelitian ini berupa kalimat atau kata-kata. Subjek dalam penelitian ini adalah kelas VIII B SMP Negeri 14 Singkawang yang berjumlah 22 siswa. Teknik pengambilan subjek penelitian ini adalah purposive sampling yaitu sesuai dengan kriteria yang diperlukan. Objek dalam penelitian ini adalah kemampuan pemahaman konsep dan koneksi matematika siswa pada materi perbandingan. Adapun teknik pengumpulan data yang digunakan dalam penelitian ini yaitu teknik pengukuran dan komunikasi langsung. Instrumen pengumpulan data menggunakan soal tes yang memenuhi beberapa indikator kemampuan pemahaman konsep dan koneksi matematika serta pedoman wawancara yang tidak terstruktur. Pengujian keabsahan data menggunakan uji kredibilitas yang dilakukan dengan cara triangulasi, meningkatkan ketekunan dan menggunakan bahan referensi. Teknik analisis data dalam penelitian ini mengacu pada pendapat Miles and Huberman (Sugiyono, 2015: 337) yang mengemukakan bahwa aktivitas dalam analisis data kualitatif dilakukan secara interaktif dan berlangsung secara terus-menerus sampai tuntas, sehingga datanya sudah jenuh. Aktivitas dalam analisis data berupa data reduction, data display, dan conclusion drawing/verification.

\section{HASIL DAN PEMBAHASAN}

\section{Kemampuan Pemahaman Konsep Matematika}

Untuk mengukur pemahaman konsep matematika siswa kelas VIII SMP Negeri 14 Singkawang digunakan instrumen berupa soal tes uraian sebanyak 3 soal materi perbandingan. Soal dirancang sesuai dengan silabus sekolah dan indikator kemampuan pemahaman konsep matematika yang hendak diukur, yaitu 1) menyatakan ulang sebuah konsep terdiri dari 1 soal; 2) memberikan contoh dan noncontoh dari konsep matematika terdiri dari 1 soal; serta 3) mengaplikasikan konsep atau algoritma ke pemecahan masalah terdiri dari 1 soal. Hasil perolehan tes kemampuan pemahaman konsep matematika siswa tersebut disajikan pada Gambar 1. 


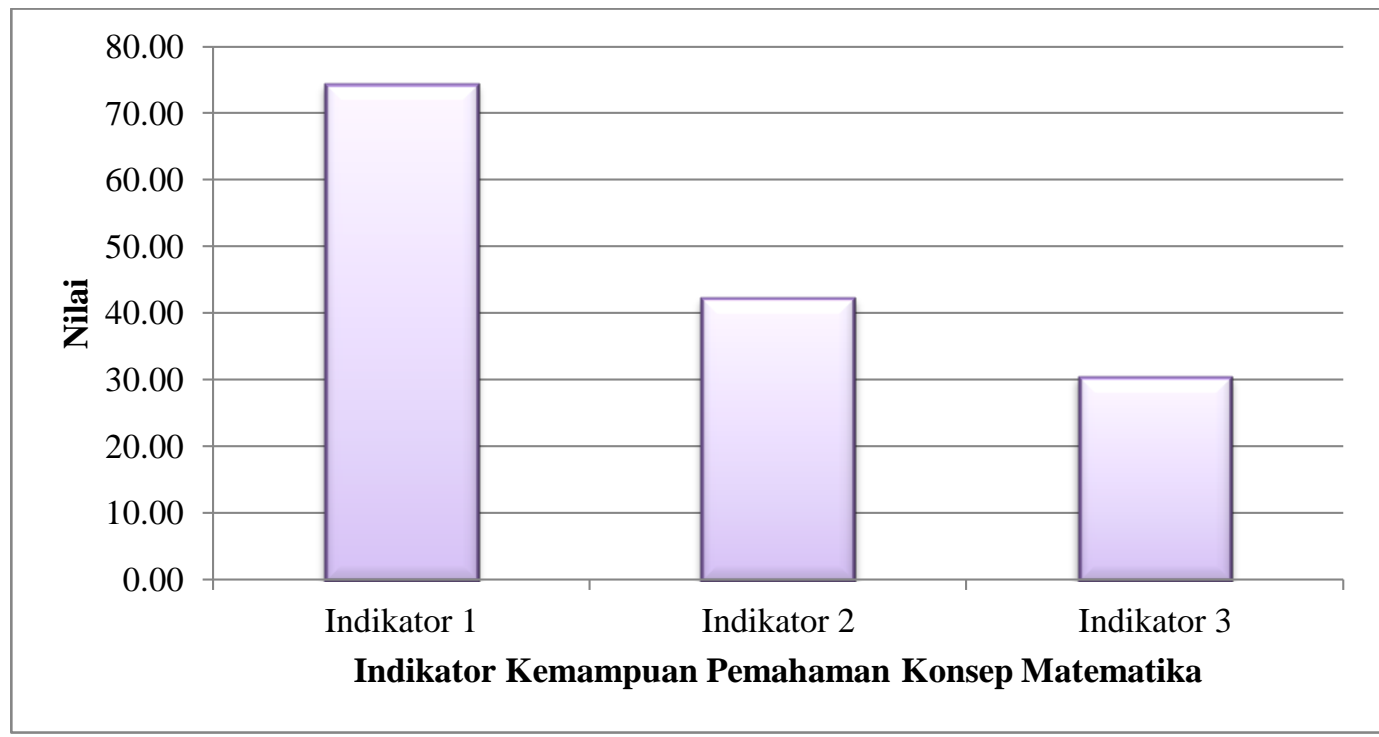

Gambar 1. Diagram Batang Hasil Tes Kemampuan Pemahaman Konsep Matematika

Pada Gambar 1, dapat diketahui bahwa kemampuan pemahaman konsep matematika siswa kelas VIII SMP Negeri 14 Singkawang yang memperoleh nilai tertinggi pada indikator 1, yaitu menyatakan ulang sebuah konsep. Sedangkan yang paling rendah adalah pada indikator 3, yaitu mengaplikasikan konsep atau algoritma ke pemecahan masalah. Hal ini berarti kemampuan pemahaman konsep matematika siswa kelas VIII SMP Negeri 14 Singkawang masih kurang terutama pada indikator memberikan contoh dan non-contoh dari konsep matematika serta mengaplikasikan konsep atau algoritma ke pemecahan masalah. Adapun rekapitulasi keseluruhan hasil tes kemampuan pemahaman konsep matematika siswa dapat dilihat pada Tabel 1.

Tabel 1. Rekapitulasi Keseluruhan Hasil Tes Kemampuan Pemahaman Konsep Matematika

\begin{tabular}{ccc}
\hline Tingkat Kemampuan Pemahaman Konsep & Jumlah Siswa & Persentase Jumlah Siswa \\
\hline Tinggi & 2 & $9,09 \%$ \\
Sedang & 7 & $31,82 \%$ \\
Rendah & 13 & $59,09 \%$ \\
\hline Jumlah & $\mathbf{2 2}$ & $\mathbf{1 0 0 \%}$
\end{tabular}

\section{Kemampuan Koneksi Matematika}

Untuk mengukur kemampuan koneksi matematika siswa kelas VIII SMP Negeri 14 Singkawang juga menggunakan soal tes berbentuk uraian dengan jumlah soal sebanyak 5 butir. Soal dirancang sesuai dengan silabus sekolah dan indikator kemampuan koneksi matematika yang hendak diukur, yaitu 1) memahami hubungan antartopik matematika terdiri dari 3 soal; 2) menerapkan konsep matematika dengan topik disiplin ilmu lainnya terdiri dari 1 soal; serta 3) menerapkan konsep matematika dalam kehidupan sehari-hari terdiri dari 1 soal. Hasil perolehan tes kemampuan koneksi matematika siswa tersebut disajikan pada Gambar 2.

Pada Gambar 2, dapat diketahui bahwa kemampuan koneksi matematika siswa kelas VIII SMP Negeri 14 Singkawang yang memperoleh nilai tertinggi pada indikator 1, yaitu memahami hubungan antartopik matematika. Sedangkan yang paling rendah adalah pada indikator 3, yaitu menerapkan konsep matematika dalam kehidupan sehari-hari. Hal ini berarti kemampuan koneksi matematika yang paling sulit adalah pada indikator menerapkan konsep matematika dalam kehidupan sehari-hari. Adapun rekapitulasi keseluruhan hasil tes kemampuan koneksi matematika siswa dapat dilihat pada Tabel 2. 


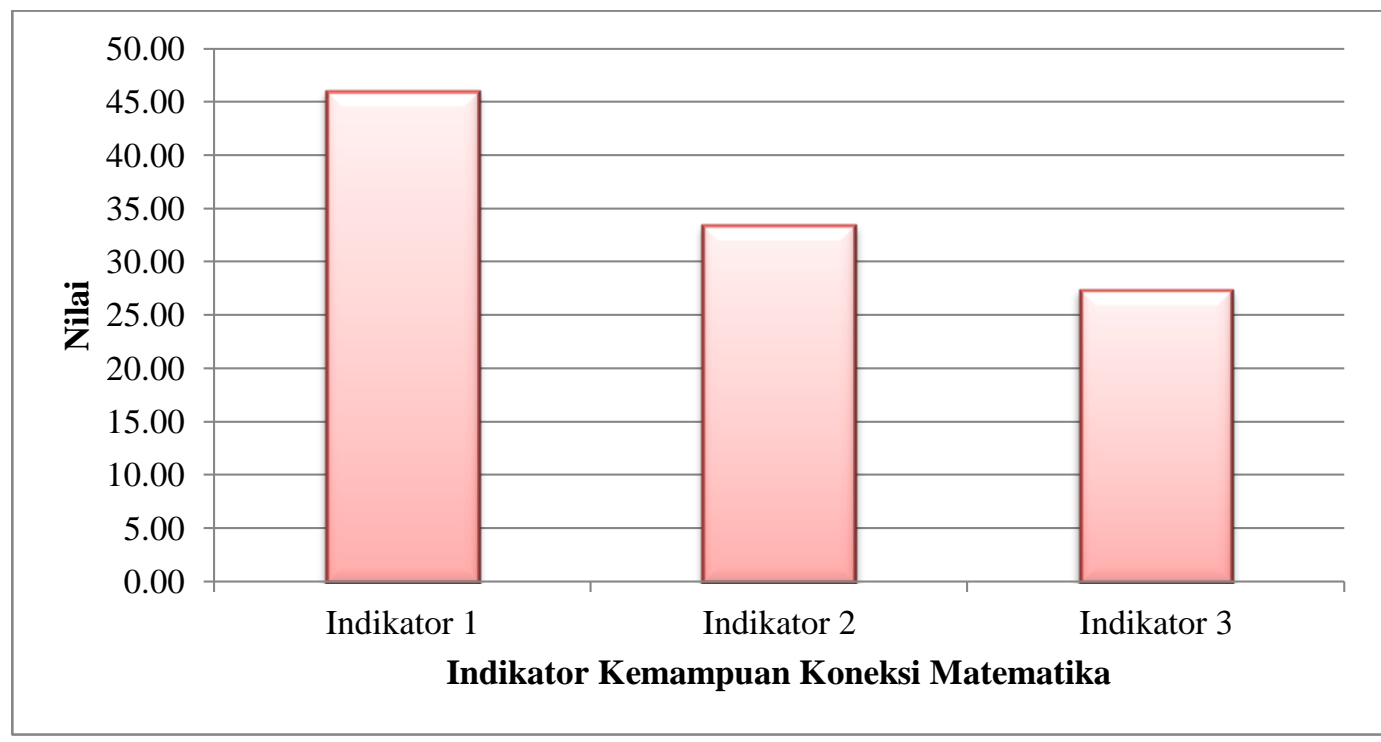

Gambar 2. Diagram Batang Hasil Tes Kemampuan Koneksi Matematika

Tabel 2. Rekapitulasi Keseluruhan Hasil Tes Kemampuan Koneksi Matematika

\begin{tabular}{ccc}
\hline Tingkat Kemampuan Koneksi & Jumlah Siswa & Persentase Jumlah Siswa \\
\hline Tinggi & 1 & $4,55 \%$ \\
Sedang & 5 & $22,73 \%$ \\
Rendah & 16 & $72,72 \%$ \\
\hline Jumlah & $\mathbf{2 2}$ & $\mathbf{1 0 0 \%}$ \\
\hline
\end{tabular}

Keterkaitan Kemampuan Pemahaman Konsep Matematika terhadap Kemampuan Koneksi Matematika

Sebelum melakukan tes kemampuan pemahaman konsep dan koneksi matematika, terlebih dahulu dilihat kemampuan awal siswa yang didapat dari hasil ulangan umum siswa. Berikut rekapitulasi kemampuan awal siswa disajikan dalam Tabel 3.

Tabel 3. Kemampuan Awal Siswa

\begin{tabular}{ccc}
\hline Kriteria & Jumlah Siswa & Persentase Jumlah Siswa \\
\hline Tinggi & 3 & $13,64 \%$ \\
Sedang & 5 & $22,73 \%$ \\
Rendah & 14 & $63,63 \%$ \\
\hline Jumlah & $\mathbf{2 2}$ & $\mathbf{1 0 0 \%}$ \\
\hline
\end{tabular}

Pada Tabel 3 dapat disimpulkan bahwa sebagian besar siswa memiliki kemampuan matematika dengan kategori rendah. Berikut disajikan pada Tabel 4 hasil tes kemampuan pemahaman konsep dan koneksi siswa kelas VIII pada materi perbandingan yang memiliki kemampuan awal tinggi.

Tabel 4. Tingkat Kemampuan Pemahaman Konsep Dan Koneksi Matematika Siswa Dengan Kemampuan Awal Tinggi

\begin{tabular}{ccc}
\hline Kode Siswa & $\begin{array}{c}\text { Tingkat Kemampuan Pemahaman } \\
\text { Konsep Matematika }\end{array}$ & $\begin{array}{c}\text { Tingkat Kemampuan Koneksi } \\
\text { Matematika }\end{array}$ \\
\hline S-11 & Sedang & Tinggi \\
S-18 & Rendah & Rendah \\
S-22 & Tinggi & Sedang \\
\hline
\end{tabular}

Pada Tabel 4 terlihat bahwa siswa yang memiliki tingkat kemampuan awal tinggi, tidak memungkinkan bahwa kemampuan pemahaman konsep dan koneksinya juga tinggi. Pada Tabel 5 
disajikan hasil tes kemampuan pemahaman konsep dan koneksi siswa kelas VIII pada materi perbandingan yang memiliki kemampuan awal sedang.

Tabel 5. Tingkat Kemampuan Pemahaman Konsep Dan Koneksi Matematika Siswa Dengan Kemampuan Awal Sedang

\begin{tabular}{ccc}
\hline Kode Siswa & $\begin{array}{c}\text { Tingkat Kemampuan Pemahaman } \\
\text { Konsep Matematika }\end{array}$ & $\begin{array}{c}\text { Tingkat Kemampuan Koneksi } \\
\text { Matematika }\end{array}$ \\
\hline S-01 & Rendah & Rendah \\
S-08 & Sedang & Sedang \\
S-12 & Rendah & Rendah \\
S-16 & Rendah & Rendah \\
S-21 & Tinggi & Sedang \\
\hline
\end{tabular}

Berdasarkan Tabel 5 terlihat bahwa siswa yang memiliki kemampuan awal sedang, dapat memungkinkan kemampuan pemahaman konsep dan koneksinya tinggi maupun rendah. Sementara itu, pada Tabel 6 disajikan hasil tes kemampuan pemahaman konsep dan koneksi siswa kelas VIII pada materi perbandingan yang memiliki kemampuan awal rendah.

Tabel 6. Tingkat Kemampuan Pemahaman Konsep Dan Koneksi Matematika Siswa Dengan Kemampuan Awal Rendah

\begin{tabular}{ccc}
\hline Kode Siswa & $\begin{array}{c}\text { Tingkat Kemampuan Pemahaman } \\
\text { Konsep Matematika }\end{array}$ & $\begin{array}{c}\text { Tingkat Kemampuan Koneksi } \\
\text { Matematika }\end{array}$ \\
\hline S-02 & Rendah & Rendah \\
S-03 & Sedang & Rendah \\
S-04 & Rendah & Rendah \\
S-05 & Rendah & Rendah \\
S-06 & Rendah & Rendah \\
S-07 & Rendah & Rendah \\
S-09 & Rendah & Rendah \\
S-10 & Rendah & Rendah \\
S-13 & Sedang & Sedang \\
S-14 & Rendah & Rendah \\
S-15 & Rendah & Rendah \\
S-17 & Sedang & Rendah \\
S-19 & Sedang & Rendah \\
S-20 & Sedang & Sedang \\
\hline
\end{tabular}

Pada Tabel 6 siswa dengan kemampuan awal rendah akan berkemungkinan pemahaman konsep dan koneksinya akan rendah pula, tetapi ada sebagian kecil yang memperoleh kategori sedang. Jadi siswa dengan kemampuan awal tinggi belum tentu memiliki kemampuan pemahaman konsep dan koneksi yang tinggi pula, siswa dengan kemampuan awal sedang belum tentu memiliki kemampuan pemahaman konsep dan koneksi yang sedang pula. Namun, siswa dengan kemampuan awal rendah berkemungkinan akan memiliki kemampuan pemahaman konsep dan koneksi yang rendah pula.

Berdasarkan kesimpulan hasil wawancara dapat diperoleh bahwa: (1) siswa dengan tingkat pemahaman konsep berkategori sedang, namun tingkat kemampuan koneksinya rendah. Hal ini disebabkan karena siswa hanya memahami satu konsep matematika, tetapi pada materi atau konsep matematika yang lain pemahamannya masih kurang; (2) siswa dengan tingkat pemahaman konsep sedang dan kemampuan koneksi matematika juga berkategori sedang. Pada hal ini, kemampuan siswa dalam memahami konsep dari berbagai materi atau topik matematika masih di atas rata-rata. Sehingga kemampuan pemahaman konsep dan koneksinya seimbang; (3) siswa dengan tingkat kemampuan pemahaman konsep sedang, namun tingkat kemampuan pemahaman koneksi matematikanya tinggi. Hal ini disebabkan karena kemampuan pemahaman konsep pada suatu materi masih kurang, namun pemahaman konsep pada bidang ilmu lainnya tinggi; (4) siswa dengan tingkat kemampuan 
pemahaman konsep tinggi, namun kemampuan koneksi matematikanya sedang. Pada hal ini, ia hanya menguasai satu materi saja tetapi pada konsep atau materi matematika maupun bidang ilmu lainnya masih di atas rata-rata; (5) siswa dengan tingkat kemampuan pemahaman konsep rendah dan kemampuan koneksi matematika juga rendah. Pada hal ini, kemampuan pemahaman konsepnya sangat kurang. Ia tidak memahami berbagai materi atau topik matematika yang telah dipelajarinya, sehingga kemampuan koneksi matematika juga rendah.

Berdasarkan hasil tes dan wawancara dapat disimpulkan bahwa sebagian besar siswa tidak memahami konsep matematika dengan baik, mereka hanya menghafal rumus sehingga mudah lupa pada pengetahuan lama yang telah mereka pelajari setelah mendapatkan pengetahuan baru. Karena pemahaman konsep siswa kurang baik, maka mereka kesulitan dalam menghubungkan antarmateri matematika maupun dengan bidang ilmu lainnya. Hal ini sesuai dengan pendapat Karso dkk. (2007: 1.40) bahwa matematika merupakan suatu ilmu yang berhubungan dengan penelaahan bentuk-bentuk atau struktur-struktur yang abstrak dan hubungan di antara hal-hal itu. Untuk dapat memahami struktur serta hubungan-hubungannya diperlukan penguasaan tentang konsep-konsep yang terdapat dalam matematika, seiring dengan pendapat Sardiman (2016: 37) bahwa belajar merupakan proses mengasimilasikan dan menghubungkan pengalaman atau bahan yang dipelajarinya dengan pengertian yang sudah dimiliki, sehingga pengertiannya menjadi berkembang. Oleh karena itu, terdapat keterkaitan kemampuan pemahaman konsep terhadap koneksi matematika, antara lain sebagai berikut:

a. Indikator kemampuan pemahaman konsep matematika yaitu menyatakan ulang sebuah konsep berkaitan dengan indikator kemampuan koneksi yaitu memahami hubungan antartopik matematika. Jika siswa hanya memahami satu konsep saja tanpa memahami konsep matematika lainnya, maka ia akan kesulitan dalam menyelesaikan masalah yang saling berhubungan antarkonsep maupun antartopik matematika yaitu berkaitan dengan kemampuan koneksi siswa.

b. Indikator kemampuan pemahaman konsep matematika yaitu memberikan contoh dan non-contoh dari konsep matematika berkaitan dengan kemampuan koneksi pada indikator menerapkan konsep matematika dengan topik disiplin ilmu lainnya. Siswa dikatakan telah memahami suatu konsep apabila ia dapat memberikan atau membuat contoh yang merupakan ciri-ciri atau kriteria dari konsep tersebut. Apabila siswa telah memahami suatu konsep, maka ia akan mudah menerapkan suatu konsep matematika dalam bidang ilmu lainnya yang berkaitan.

c. Indikator kemampuan pemahaman konsep matematika yaitu mengaplikasikan konsep atau algoritma ke pemecahan masalah berkaitan dengan kemampuan koneksi yaitu menerapkan konsep matematika dalam kehidupan sehari-hari. Dikatakan telah memahami suatu konsep apabila dapat menerapkan, menggunakan atau mengaplikasikan konsep untuk memecahkan masalah matematika. Jika siswa sudah bisa menerapkan konsep tersebut, maka ia akan bisa untuk menyelesaikan permasalahan dalam kehidupan sehari-hari yang berkaitan dengan konsep matematika.

Hasil penelitian ini seiring dengan penelitian Kusmanto \& Marliyana (2014: 61) yang menunjukkan bahwa pemahaman matematika memiliki pengaruh pada kemampuan koneksi matematika dengan koefisien determinasi ( $R$ Square) sebesar 37,9\% dengan persamaan regresi $\mathrm{Y}=36,713+0,485 \mathrm{X}$, yang menyatakan bahwa setiap peningkatan pemahaman matematika akan mempengaruhi peningkatan kemampuan koneksi sebesar 0,485 .

\section{KESIMPULAN}

Berdasarkan hasil penelitian yang telah dilaksanakan di SMP Negeri 14 Singkawang, maka dapat disimpulkan bahwa tingkat kemampuan pemahaman konsep matematika siswa pada materi perbandingan adalah 2 siswa dengan kemampuan pemahaman konsep tinggi, 7 siswa dengan kemampuan pemahaman konsep sedang dan 13 siswa dengan kemampuan pemahaman konsep rendah. Adapun tingkat kemampuan koneksi matematika siswa pada materi perbandingan adalah 1 siswa dengan kemampuan koneksi tinggi, 5 siswa dengan kemampuan koneksi sedang dan 16 siswa dengan kemampuan koneksi rendah. Tingkat kemampuan pemahaman konsep matematika berkaitan dengan tingkat kemampuan koneksi matematika. Adapun keterkaitan antar indikator kemampuan pemahaman konsep terhadap koneksi matematika yaitu (1) indikator menyatakan ulang sebuah konsep berkaitan 
dengan memahami hubungan antartopik matematika; (2) indikator memberikan contoh dan noncontoh dari konsep matematika berkaitan dengan menerapkan konsep matematika dengan topik disiplin ilmu lainnya; dan (3) indikator mengaplikasikan konsep atau algoritma ke pemecahan masalah berkaitan dengan menerapkan konsep matematika dalam kehidupan sehari-hari.

\section{DAFTAR PUSTAKA}

Hernawan, Asep Herry, Susilana, Rudi, Julaeha, Siti \& Sanjaya, Wina. (2010). Pengembangan Kurikulum dan Pembelajaran. Jakarta: Universitas Terbuka

Ibrahim dan Suparni. (2012). Pembelajaran Matematika Teori dan Aplikasinya. Yogyakarta: SUKAPress UIN Sunan Kalijaga

Karso, Suyadi, Gimin, Muhsetyo, Gatot, Chadra, Tjang Daniel, Widagdo, Djamus \& Priatna, Nanan. (2007). Pendidikan Matematika I. Jakarta: Universitas Terbuka

Kusmanto, Hadi \& Marliyana, Iis. (2014). "Pengaruh Pemahaman Matematika Terhadap Kemampuan Koneksi Matematika Siswa Kelas VII Semester Genap SMP Negeri 2 Kasokandel Kabupaten Majalengka". Jurnal EduMa, 3(2), 61-75.

Lestari, Karunia Eka \& Yudhanegara, Mokhammad Ridwan. (2015). Penelitian Pendidikan Matematika. Bandung: PT Refika Aditama

Mariyam \& Wahyuni, Rika. (2016). Mengembangkan Kemampuan Penalaran Matematis Siswa Melalui Problem Centered Learning Pada Materi Peluang (Studi Eksperimen Di Kelas VIII SMP N 6 Singkawang). Jurnal Pendidikan Matematika Indonesia, 1(2), 74-80.

Prihatiningtyas, Nindy Citroresmi \& Nurhayati. (2017). Penerapan Model Pembelajaran Means-Ends Analisys Untuk Meningkatkan Kemampuan Pemecahan Masalah Matematis Siswa. Jurnal Pendidikan Matematika Indonesia, 2(1), 13-18.

Sardiman. (2016). Interaksi \& Motivasi Belajar Mengajar. Jakarta: Rajawali Pers

Sugiyono. (2015). Metode Penelitian Pendidikan Pendekatan Kuantitatif, Kualitatif dan $R \& D$. Bandung: Alfabeta.

Suryani, Elsa. (2016). Analisa Pemahaman Konsep Matematis Siswa Pada Materi Operasi Hitung Bilangan Bulat Kelas VII Mts Ushuluddin Singkawang. Skripsi. STKIP Singkawang. Tidak Dipublikasikan. 